http://kitaibelia.unideb.hu/

ISSN 2064-4507 (Online) • ISSN 1219-9672 (Print)

(C) Department of Botany, University of Debrecen, Hungary

26(2): 131-144.; 2021

DOI: $10.17542 /$ kit.26.131

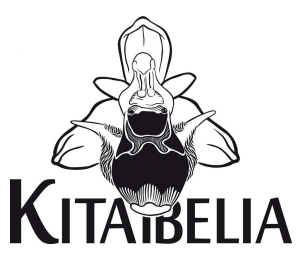

\title{
Az Equisetum × moorei és $E$. hyemale nyírségi elterjedésének kritikai áttekintése
}

\author{
DEMETER László* \& LESKU Balázs \\ Hortobágyi Nemzeti Park Igazgatóság, H-4024 Debrecen, Sumen u. 2.; *demeterlaszlo@hnp.hu
}

\section{Critical review of the distribution of Equisetum $\times$ moorei and E. hyemale in the Nyírség (East Hungary)}

\begin{abstract}
Confusing Moore's horsetail (Equisetum $\times$ moorei Newman) with rough horsetail (Equisetum hyemale L.) is a known problem in many countries. In our paper, we review some of the features used for their identification concerning their usability. We examined Equisetum hyemale stands in the Nyírség reported in the literature and E. hyemale specimens of the Herbarium of the University of Debrecen that were collected in the Nyírség. We found that most of these stands and herbarium specimens are actually E. × moorei. The occurrence of $E$. hyemale was only confirmed in Bátorliget. We also report several new occurrences of Equisetum $\times$ moorei in the Nyírség. To better separate the two taxa, we recommend micromorphological examination of the surface of the shoots, which can be performed in the field, as well as observing the height of the leaf-sheath.
\end{abstract}

Keywords: distribution, East Hungary, Equisetum hyemale, Equisetum × moorei, horsetails, morphology, Nyírség region

Összefoglaló - A hibrid eredetű Moore-zsurló (Equisetum $\times$ moorei Newman) összetévesztése a téli zsurlóval (Equisetum hyemale L.) számos országban ismert probléma. Közleményünkben áttekintjük a határozáshoz alkalmazott bélyegek egy részét, kiemelve azok tényleges használhatóságát. Megvizsgáltuk a téli zsurló régebbi irodalmakban megadott nyírségi állományait és a Debreceni Egyetem Herbáriumában található nyírségi példányokat. Megállapítottuk, hogy többségük valójában Moore-zsurló. A téli zsurló előfordulását csak Bátorligeten tudtuk megerősíteni. Számos új adatot közlünk a Moore-zsurló nyírségi előfordulásáról is. A két taxon jobb elkülönítéséhez javasoljuk a hajtások felszínének terepen is elvégezhető mikromorfológiai vizsgálatát, valamint a levélhüvely magasságának megfigyelését.

Kulcsszavak: elterjedés, Equisetum hyemale, Equisetum × moorei, Kelet-Magyarország, morfológia, Nyírség, zsurlófélék

\section{Bevezetés}

A téli zsurló (Equisetum hyemale L.) SEREGÉLYEs (1999) szerint könnyen felismerhető faj, de régi adatai részben kétesek, jórészt a Moore-zsurlóra (Equisetum × moorei Newman) vonatkoznak, amire már JÁvORKA \& Soó (1951) is felhívta a figyelmet. A világhálón, illetve a közösségi médiában számos fénykép látható tévesen téli zsurlóként feliratozva, miközben Moorezsurlót ábrázolnak, de a téves azonosítás az utóbbi idők hazai florisztikai adatai között is fellelhető. A határozási probléma persze nem csak nálunk fordul elő. Hollandiában például DE WINTER \& LUBIENSKI (2012) az E. hyemale régebbi előfordulási adatainak és herbáriumi példányainak revíziója során azt tapasztalta, hogy több mint felük $E$. × moorei-nek bizonyult. A 
Moore-zsurló csehországi előfordulásaival kapcsolatban HRouDA (1997) is megjegyzi, hogy gyakran összetévesztik a téli zsurlóval, és hasonlóról számol be LUBIENSKI et al. (2012) ÉszakRajna-Vesztfália területéről. A két taxon hasonlóságának oka, hogy a Moore-zsurló az $E$. hyemale L. és E. ramosissimum Desf. diploid hibridje, így morfológiai jellegei átmenetet mutatnak a két faj között (DE WINTER \& LUBIENSKI 2012, LUBIENSKI et al. 2012, PÉTREMENT et al. 2012, KALINOWSKI et al. 2016).

A hibrid spórái sterilek, így terjedése feltehetően csak vegetatívan, a gyöktörzs darabkáival történhet (KALINOWSKI et al. 2016). Ezek szállításában akár a folyóvíz vagy a tenger is szerepet játszhat (PÉTREMENT et al. 2012). Előfordulása láthatóan nem kötődik a két szülőfaj együttes jelenlétéhez. Az európai kontinens alacsonyabb fekvésű tájain többnyire csak a hosszú zsurlóval él közvetlen közelségben (HROUDA 1997, KALINOWSKI et al. 2016). Ennek az elterjedési mintának a magyarázatára már KüMMERLE (1931) felvetett egy elméletet. Szerinte a jégkorszak idején az Equisetum hyemale benépesítette az alacsony medencék területeit. A jégkorszakot követő felmelegedés során a balkáni és mediterrán elemek között az Equisetum ramosissimum is benyomult ezekre a területekre, és ekkor kerülhetett sor nagyobb arányban a hibridizációra. Később a boreális E. hyemale visszahúzódott a hegyvidékekre, illetve az északi tájakra. A hibrid azonban jó vegetatív szaporodási képességének köszönhetően máig fennmaradt ezeken a vidékeken. Ha a gondolatot a Nyírséggel kapcsolatban továbbgörgetjük, adódik a feltevés, hogy az itteni homokbuckák közé ékelődő lápterületek környezete a jégkorszak után akár hosszabb ideig is refúgiumként szolgálhatott a téli zsurló számára, hasonlóan más növényfajokhoz. Ennek következtében a hibridizáció lehetősége jóval tovább fennállhatott. Ebből az is következhet, hogy a Moore-zsurló a Nyírségben elterjedtebb lehet a környező alföldi területekhez képest, illetve esetleg morfológiailag is változatosabb. Másrészt azt is várhatnánk, hogy a téli zsurló e refúgiumokban ma is számos helyen megtalálható, amit néhány irodalmi adat is megerősíteni látszik.

Az Equisetum hyemale nyírségi adatai közül a bátorligeti lápról származó a legismertebb (pl. Boros 1924, Soó 1964, StANDovár et al. 1991, PAPP \& LESKU 2002, TinYA 2005). ÖTVÖS (1965) kimondottan a bátorligeti Fényi-erdőből írja. Az ezredforduló táján Rév et al. (2005) viszont nem találta itt meg, míg HoRváth et al. (2018) cönológiai felvételben ismét jelzi előfordulását. BOROS (1924) a Kispiricsei-erdőből is írja. PAPP (2003) Vámospércs határából jelzi, a Jónásrésznek nevezett terület zergeboglár-állománya mellett. KORDA \& SzIGETVÁRI (2013) Nyíregyházán a Sóstói-erdőből, Kevey et al. (2017) Nyíradonyban a Gúti-erdőből, KoRDA et al. (2017) Álmosdon, a Daru-láp déli részéről, MATus et al. (2019) pedig Vámospércsen a Villongó-víztározó keleti szivárgó árkából írja le. Az OBM - Magyarország Flóratérképezési Adatbázisa (BARTHA et al. 2021) a Tiszától keletre Lesku Balázs bátorligeti rekordján kívül Király Gergely baktalórántházai és Szigetvári Csaba újfehértói flóratérképezési adatát mutatja a megtekintés idején, a már irodalmi adat formájában is említett vámospércsi mellett. A Debreceni Egyetem Herbáriumában őriznek három példányt Siroki Zoltán 1956-os gyűjtéséből Bátorligetről (TAKÁCS et al. 2015), valamint egyet-egyet Süveges Kristóf 2018-as gyűjtéséből Sárándról és Matus Gábortól Vámospércsről, a már említett helyszínről. A fentieken kívül ismert még számunkra néhány olyan nem közölt adata is, melyek a Hortobágyi Nemzeti Park Igazgatóság munkatársaitól származnak. Ezek közé tartozik Barczánfalvi Péter (2018) nyírcsaholyi és Szigetvári Csaba (2013) Bátorliget-újtanyai, valamint Máté Rudolf (2013) Fényierdőből való észlelése. A Nyírségnek a jelenlegi Romániába átnyúló térségéből ARDELEAN \& KARÁCSONYI (2005) által összegyüjtött irodalmi és egyéb adatok szerinti előfordulását jelezték a következő lelőhelyekről: Csanálos (Urziceni), Mezőfény (Foieni), Reszege (Resighea), Szaniszló (Sanislau), Érkörtvélyes (Curtuiuseni), Érmihályfalva (Valea lui Mihai), Érsemjén (Simian).

Az Equisetum × moorei szintén jól ismert a bátorligeti lápról (STANDovár et al. 1991). A bátorligeti Fényi-erdőből Soó (1934) szintén jelzi, majd rá hivatkozva ÖTVös (1965), míg Rév et 
al. (2005) recens előfordulását adja. RAPAICS (1922) „E. hiemale L. f. Moorei Newman” néven említi Halápról. Soó (1932) közli a Sárándi-erdőből, majd kiegészíti a Hajdúbagosi-erdővel, Hajdúhadházi-erdővel (Soó 1934), a debreceni Pac-erdővel és a teremi (vállaji) Bodvaierdővel (Soó 1937). UBRIZsy (1936) „e. Schleicherii” néven említi a „nyíregyházi erdőből”. Az OBM - Magyarország Flóratérképezési Adatbázisa (BARTHA et al. 2021) ezen kívül a megtekintett állapotban a Tiszától keletre mindössze egyetlen flóratérképezési adatot közöl Döge határából Szigetvári Csabától, ami az adatközlő részletes tájékoztatása szerint a két település között, de valójában Kékcse határában van. Ez a helyszín formálisan nem a Nyírséghez, hanem a Rétközhöz tartozik, viszont a talaja alapvetően homokos [1], a két középtáj határán fekszik. A Debreceni Egyetem Herbáriumában számos példány található Soó Rezsőtől Bagamér (1933), Bátorliget (1932) és a bátorligeti Fényi-erdő (1934), Bocskaikert (1934), Debrecen-Pac (1934), Hajdúbagos (1933), Hosszúpályi (1933), Nyírlugos (1947), Sáránd (1932) és Vállaj (1934) területéről. „E. hiemale L. f. Moorei Newman” névvel ellátott példány található ugyanitt Siroki Zoltán 1947-es gyűjtéséből a debreceni Nagyerdőből. A Nyírségnek a jelenlegi Romániába átnyúló térségéből ARDELEAN \& KARÁCSONYI (2005) által összegyűjtött irodalmi adatok szerint a Moore-zsurló előfordulását jelezték a következő lelőhelyekről: Csanálos (Urziceni), Mezőfény (Foieni), Károlyipuszta (Horea), Piskolt (Piscolt), Érmihályfalva (Valea lui Mihai).

A közlemény célja a téli zsurló nyírségi előfordulásainak tisztázása, a Moore-zsurló újabb adatainak közlése, valamint a pontosabb határozást elősegítő néhány morfológiai jelleg áttekintése.

\section{Morfológiai különbségek és határozás}

A téves azonosítások hazánkban többnyire abból adódhatnak, hogy a rendelkezésre álló határozók és más szakkönyvek a két taxon elkülönítéséhez viszonylag kevés és részben nem egyértelmú bélyeget adnak meg. Soó (1964), Soó \& KÁRPÁTi (1968) és SimON (2000) például az E. × moorei-ről azt írja, hogy szára nem kitelelő, míg KIRÁLY (2009) úgy fogalmaz, hogy a szár általában nem telel át. Ez egybecseng JÁVORKA (1924-1925) leírásával, valamint KüMMERLE (1931) cikkében is azt olvashatjuk, hogy általában nem, de néha áttelel. A nyírségi állományokban azonban adatgyüjtésünk idején télen is zöldellt a hajtások nagy része, miközben a hajtások csúcsa rövidebb-hosszabb szakaszon visszaszáradhatott, és persze teljesen elszáradt hajtások is előfordultak változó mennyiségben. Hasonlóról számol be DE WINTER \& LUBIENSKI (2012), akik szerint részben áttelel a tél hidegségétől függően, néha csak a szár felső része szárad el. LUBIENSKI et al. (2012) is arról ír, hogy általában nem teljes mértékben áttelelő, a hajtás felső részei elhalnak. Az áttelelés tehát nem tekinthető jó elkülönítő bélyegnek. Annál is inkább, mivel például 2020 tavaszán még a hosszú zsurlóból is sokfelé lehetett találni áttelelt hajtásokat. Ráadásul megfigyelésünk szerint a tél végére a téli zsurló hajtásainak végén is lehetnek elszáradt szakaszok.

Az Új magyar füvészkönyv (KIRÁLY 2009) szerint az E. hyemale szárának levélhüvelyei felső és alsó részükön 1-1 fekete szalagot viselnek, míg az E. × moorei levélhüvelyei általában csak felső részükön viselnek fekete szalagot. Ennek ellentmond, hogy a FERRER-GALLEGo et al. (2017) által kijelölt - David Moore gyújtéséből származó - E. × moorei lektotípus közzétett fotóján a levélhüvelyek alján és tetején is látható fekete szalag, ahogy a LUBIENSKI (2010) és KALINOWSKI et al. (2016) publikációjában látható fényképeken, illetve WATSON \& DALLWITZ (2004) leírásában is ez szerepel. Az általunk ismert állományok zömére is ez jellemző. Máskor éppen a felső szalag hiányzik, ahogy egy nyírábrányi állományban tapasztaltuk, vagy LUBIENSKI et al. (2012) cikkének képén is látható. Az E. hyemale-nél is előfordul a felső szalag hiánya, amire SEREGÉLYES (1999) leírása mellett Farkas Sándornak a publikáció illusztrációja- 
ként megjelent képén láthatunk példát. A kérdést persze árnyalja, hogy a fekete szalagoknak ez a mintázata a teljesen kifejlett, sötétzöld hajtásokon figyelhető meg, amikor a levélhüvely is fehéres, esetleg barnás színezetűre változott. A fiatalabb hajtások zöldessárgás levélhüvelyein általában valóban csak felül látható keskeny fekete szalag mindkét taxonnál. Az alsó csak később alakul ki, így változatos átmeneti mintázatokkal is találkozhatunk egy ideig. Ráadásul egyes példányokon a fekete színezetű részek kiterjedése és alakja is változatos lehet (1. ábra). Akár teljesen fekete levélhüvely is előfordul, amiről JÁvORKA (1924-1925), KÜMMERLE (1931), Soó \& KÁRPÁTi (1968) és LUBIENSKI et al. (2012) is beszámol az E. hyemale esetén. A hibridnél szintén megfigyeltünk ilyen hajtásokat.
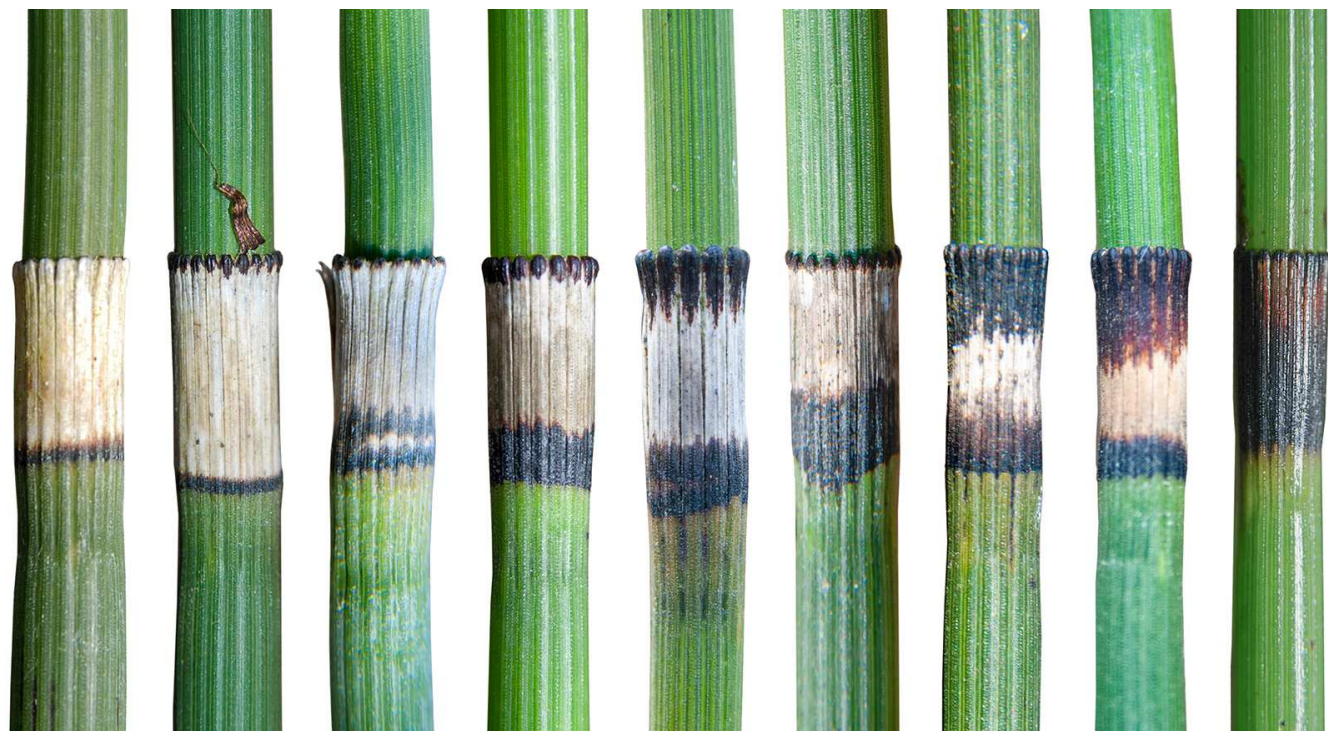

1. ábra Az Equisetum × moorei változatos mintázatú levélhüvelyei a nyírségi állományokból

Fig. 1 Diverse patterns of the leaf-sheaths of Equisetum $\times$ moorei specimens from the Nyírség stands

Az újabb hazai határozók nem említik, hogy a két taxon levélhüvelyének méretében többnyire jól érzékelhető különbség mutatkozik. Korábban viszont JÁvORKA (1924-1925) azt írta, hogy az E. hyemale esetén a levélhüvelyek szélességüknél nem, vagy alig hosszabbak, míg az E. × moorei esetén majdnem még egyszer olyan hosszúak, mint szélesek. A nemzetközi irodalomban is számos, ezzel egybehangzó megfogalmazást találunk (HroudA 1997, STACE 2010, FERRER-GALLEGO et al. 2017). Más szerzők kevésbé sarkosan úgy fogalmaznak, hogy az $E$. hyemale esetén a levélhüvely magassága megegyezik a hajtás vastagságával vagy kicsit magasabb, az E. × moorei esetén pedig mindig magasabb (DE WINTER \& LUBIENSKI 2012, LUBIENSKI et al. 2012). Fontos megjegyezni, hogy ezt a tulajdonságot a teljesen kifejlett szár középső részén érdemes megítélni, mivel a végek felé a levélhüvely rövidül. Másrészt több hajtáson érdemes megnézni, mert tapasztalataink szerint a Moore-zsurló vékony hajtásain gyakran rövidebbek, mint a vastagokon.

Az irodalomban ismert egy mikromorfológiai jelleg is, ami az elkülönítésben segít. Az $E$. hyemale szárán látható hosszanti bordákon különálló apró kovaszemölcsök alkotta páros sor fut végig (nem tévesztendő össze a bordák közötti barázdákban futó pontsorokkal). Az $E$. × moorei esetén ugyanitt - gyakran szabálytalan alakú - apró keresztbordázat látható, az $E$. ramosissimum-hoz némileg hasonlóan (HROUDA 1997, LUBIENSKI 2010, DE WINTER \& LUBIENSKI 2012, LUBIENSKI et al. 2012, KALINOWSKI et al. 2016, FERRER-GALLEGO et al. 2017). Olyan, mintha a kovaszemölcs párok változó mértékben középen összenőttek volna. Ez a mintázat nem ki- 
zárólagos abban az értelemben, hogy egyes hajtásrészeken (különösen a vékonyakon) a különálló kettős szemölcssor is feltűnhet (PÉTREMENT et al. 2012). Érdemes lehet tehát több hajtást és azok középső részét vizsgálni. Ezt a bélyeget mikroszkóp hiányában egy megfordított távcsővel vagy egy jó makrofelvétel felnagyításával is láthatóvá tehetjük. Áttelelő hajtásokon tavaszra ezek a kiemelkedések lekophatnak.

A szár keresztmetszeti képe a téli zsurló elkülönítésére önmagában aligha alkalmas, noha egyes források ábrái ezt sugallhatják ([2], SIMON 2000). BRUNE et al. (2008) vizsgálata szerint a Moore-zsurló szárának keresztmetszete esetenként csaknem teljesen megkülönböztethetetlen tőle. A téli zsurló internódiumai többé-kevésbé felfújtak lehetnek (Soó 1964), ami gyakran a nóduszok alatt látszik kifejezettebben.

A téli zsurló sűrű polikormonjaira általában jellemző, hogy nagyjából egyforma vastagságú, mereven felálló hajtásokból álló (WEBB et al. 1996, LUBIENSKI et al. 2012) „kefebozótot” képeznek. A Moore-zsurló érett hajtásai ellenben hajlamosak az elfekvésre (LuBIENSKI et al. 2012), ami részben abból adódik, hogy a téli zsurlóhoz képest gyakran hosszabbak a hajtásai és azok internódiumai is (JÁvORKA \& Soó 1951, Soó 1964, SimON 2000). Kifejlett hajtásai leginkább akkor maradnak függőleges helyzetben, ha támasztékot találnak a cserjék ágain. Hajtásainak vastagsága is elég változatos lehet. Az általunk vizsgált lelőhelyeken mindkét taxon alkothat szinte homogén, egybefüggő, sűrű állományokat.

Fontos megemlíteni, hogy a téli zsurlónak és a hosszú zsurlónak ismert egy triploid hibridje is Equisetum $\times$ ascendens Lubienski \& Bennert néven. Morfológiai alapon történő elkülönítése a Moore-zsurlótól igen nehéz (LUBIENSKI et al. 2012), teljesen megbízható eredményt leginkább a kromoszómák vizsgálata adhat. Előfordulása jelenleg a Rajna folyó völgyéből ismert Franciaország és Németország határvidékén, valamint néhány adata van Észak-RajnaVesztfália és Hollandia területéről (DE WINTER \& LUBIENSKI 2012).

1. táblázat A két taxon elkülönítéséhez általunk használt két legfontosabb jellemző

Table 1 The two most important characteristics we use to separate the two taxa

\begin{tabular}{lll}
\hline Jellemzők & Equisetum hyemale & Equisetum × moorei \\
\hline $\begin{array}{l}\text { LEVÉLHÜVELY MÉRETE } \\
\text { (jól kifejlett hajtások középső } \\
\text { részén nézve) }\end{array}$ & $\begin{array}{l}\text { levélhüvelyek } \\
\text { szélességüknél nem } \\
\text { vagy alig hosszabbak }\end{array}$ & $\begin{array}{l}\text { levélhüvelyek mindig hosszabbak } \\
\text { (általában 1,5-2×), mint a szélességük }\end{array}$ \\
\hline $\begin{array}{l}\text { KOVASZEMÖLCSÖS } \\
\text { MIKROMORFOLÓGIAI MINTÁZAT }\end{array}$ & $\begin{array}{l}\text { különálló apró } \\
\begin{array}{l}\text { A SZÁR HOSSZANTI BORDÁIN } \\
\text { (áttelelö hajtásokon tavaszra ezek } \\
\text { a kiemelkedénálytalan alakú } \\
\text { keresztbordázat látható, mintha a }\end{array}\end{array}$ & $\begin{array}{l}\text { káros sor fut végig } \\
\text { kovaszemölcs párok változó } \\
\text { mértékben középen összenőttek volna } \\
\text { (emellett a különálló kettős }\end{array}$ \\
\hline
\end{tabular}

\section{Anyag és módszer}

Saját előfordulási adataink 2001 óta gyúlnek a Nyírség területéről. Többségük a leggyakrabban járt Dél-Nyírségből származik. Egy ideig magunk is téli zsurlóként azonosítottuk a megtalált növényeket, majd a tévedés felismerése után a régieket is felülvizsgáltuk.

Felkerestük az E. hyemale irodalomból ismert, illetve herbáriumi példányokkal dokumentált lelőhelyeit: PAPP (2003) vámospércsi Jónásrészen, KoRDA \& SzIGETVÁRI (2013) Nyíregyházán a Sóstói-erdőben, HoRvátH et al. (2018) a bátorligeti Fényi-erdőben, KEVEY et al. (2017) Nyíradonyban a Gúti-erdőben, KoRDA et al. (2017) Álmosdon, MATUS et al. (2019) vámospércsi Villongó-víztározónál és Király (BARTHA et al. 2021) Baktalórántházi-erdőben leírt lelőhelyeit, valamint Süveges Kristóf sárándi herbáriumi példányának, Barczánfalvi Péter nyírcsaholyi, Szigetvári Csaba Bátorliget-újtanyai és Máté Rudolf Fényi-erdői adatának termőhelyét, 
részben a mikromorfológiai jellemzők vizsgálata céljából. Ezen termőhelyek mindegyikét kétséget kizáróan azonosítani lehetett a pontos leírás, a megadott koordináták, erdőrészlet vagy az egyéb forrásból rendelkezésünkre álló pontos térképi ábrázolás segítségével. Szigetvári Csaba újfehértói $E$. hyemale adatának pontos helye nem volt ismert, ezért 2020 februárjában és októberében megpróbáltuk megkeresni a megadott flóratérképezési kvadrát területén. A faj megtalálására BoROs (1924) adata alapján a Kispiricsei-erdőben is kísérletet tettünk 2020 decemberében. Minden E. hyemale néven leírt állomány esetén megvizsgáltuk a hajtások mikromorfológiáját, és digitális felvételeket készítettünk róla egy egyszerűbb USB mikroszkóppal, fényképezőgéppel vagy mobiltelefonnal egy hagyományos mikroszkópon keresztül. Az általunk talált vagy mások útmutatása alapján felkeresett $E$. × moorei-ként leírt állományok esetén is megtettük ugyanezt. Néhány esetben a Hortobágyi Nemzeti Park Igazgatóság más munkatársai jeleztek számunkra előfordulásokat, melyeket az általuk készített jó minőségű makrofelvétel alapján vizsgáltunk meg. A jelzett romániai lelőhelyeket egyelőre nem tudtuk felkeresni.

A Debreceni Egyetem Herbáriumának (DE) Soó Rezső Herbáriumában és Siroki Zoltán Herbáriumában található példányokat Demeter László nézte át mindkét taxonra vonatkozóan. Citológiai vizsgálatot a növényeken nem végeztünk.

A Moore-zsurló előfordulási adatainak listájában a lelőhelyek településhatáron belüli megnevezéséhez elsősorban a Magyarország Földrajzinév-tára (FöLDI 1981) térképét, Debrecen környékének turistatérképét, valamint az 1:10 000 méretarányú topográfiai térkép helyneveit használtuk. Helyenként zárójelben a terület pontosítását szolgáló megjegyzéseket is feltüntettünk. Csillaggal jelöltük azt a helyet, ahol a hajtások mikromorfológiájáról felvétel nem készült. Zárójelben adtuk meg a megtalálás dátumát, illetve a mintagyűjtés dátumát, ha az eltért az eredeti megtalálás idejétől. Szögletes zárójelben közöljük az előfordulási helyet lefedő KEF-kvadrát kódját. Megadtuk azt is, hogy az adott észlelés mely korábbi adat felülvizsgálatát jelenti. A növényfajok megnevezése KIRÁLY (2009) munkáját követi.

\section{Eredmények}

\section{A Moore-zsurló (Equisetum × moorei) új és felülvizsgált állományai}

Vizsgálataink eredményeképpen számos korábbi $E$. hyemale előfordulásról derült ki, hogy azok valójában az E. × moorei lelőhelyei. Emellett további új E. × moorei állományokat is találtunk. Ezeket az alábbiakban soroljuk fel, megadva, hogy milyen korábban közölt adatnak feleltethetőek meg, ha ismert korábbi említésük.

Álmosd

- Kék-Kálló (a Daru-láptól délre), láp szegélyén és pionír puhafás foltban [8597.4] (2008. 10. 09., mintagyújtés 2019. 01. 28.). Megfelel KoRDA et al. (2017) E. hyemale adatának.

Baktalórántháza

- Baktalórántházi-erdő, mesterségesen felújított fiatal tölgyes szélén és mélyebb fekvésű kökényes cserjés foltjában több, kevés hajtású polikormon [8098.1] (2020. 03. 20.). Megfelelhet Király Gergely E. hyemale flóratérképezési adatának.

- A 41. főút mentén mindkét oldalon sűrű állomány a Rohodi-legelő közelében, a 32. km táblánál [7998.4] (2020.12.16.). 
DEMETER \& LESKU (2021): Az Equisetum × moorei és E. hyemale nyírségi elterjedésének kritikai áttekintése

Bátorliget

- Oôsláp, ligeterdő üde rét menti szegélyén szórványos hajtáscsoportok [8299.2] (2020. 03. 20.). Megfeleltethető TiNYA (2005) E. hyemale „új” adatának, ami a közismert, nagy állománytól távolabbi kis egyedszámú előfordulásra vonatkozik.

- Újtanya, a nyírpilisi községhatár mentén vaskos, néhol embermagasságú hajtások kisebb csoportjai [8299.3] (2020. 12. 16.). Megfelel Szigetvári Csaba 2013-as nem közölt E. hyemale adatának. Fényi-erdő, Égett kocka, keményfaliget állományban szórványosan néhány hajtáscsoport [8299.4] (2021. 03. 19.). Megfelel HoRváTH et al. (2018) E. hyemale adatának.

- Fényi-erdő, erdőssztyepp jellegű homoki tölgyes tisztásán elszórtan néhány hajtáscsoport, üde tölgyerdő foltok közelében [8299.4] (2021. 03. 19.). Megfelel Máté Rudolf (HNPI) 2013-as, nem közölt E. hyemale adatának.

Bocskaikert

- Váci Mihály út végén, a vasút menti töltésen sűrű polikormonok, de a településnél áthaladó vasút mentén máshol is előfordul [8396.3] (2020. 01. 23.). Patalenszki Norbert (HNPI) találta.

Debrecen

- $\quad$ Nyárfa-lapos-dűlő, a Pályi-ér átereszénél [8596.2] (2017. 03. 08.).

- Haláp, a Szárcsás-ér hídjánál [8596.2] (2017. 03. 21.).

- Rauchbauer-erdő, kevés hajtás elegyes faállomány nedves foltjában [8497.1] (2018. 08. 09., mintagyújtés 2020. 03. 19.).

- Rauchbauer-erdő, a Gúti-ér hídjánál sűrű állomány [8497.3] (2019. 01. 18.).

- Haláp-szél, a Gúti-ér hídjánál [8497.3] (2019. 01. 18.).

- Bodzás-tározótól északkeletre, a Bodzás-ér hídjánál [8496.4] (2019. 01. 29.).

- Soma, a Bodzás-ér hídjánál [8497.1] (2019. 03. 01.).

- Bánki-erdő [8596.2] (2019. 09. 10.).

- Nagy-tag, idősebb homoki tölgyesben kis hajtáscsoport [8496.2] (2020. 01. 15.).

- Fancsika, a Panoráma út nyugati oldalán, erdőszélen ritkás állomány [8596.1] (2020. 01. 28.).

- Halápi-erdő, a nyírábrányi vasútvonal töltésén cserjés alatt és a szomszédos fiatal tölgyes szélén [8497.3] (2020.03.26.).

- Sámsoni úti Bellegelő, egy mesterségesen megmagasított homokbucka csúcsának északi oldalán [8496.1] (2020. 04.03.),

- Bánki-erdő, 14 éves tölgyes felújításban szórványos hajtáscsoportok [8596.2] (2020. 04. 15.).

- Paci-erdő, kis hajtáscsoport erdei fenyves szélén [8596.1] (2020. 06. 26.).

- Halápi-erdő középső része, keményfás ligeterdő jellegű állomány szélén, egy homokbucka alján [8596.2] (2020. 06. 26.).

- Cserei-dűlő az Acsádi út és a Zsuzsi Vasút Erdészlak megállója között egy tölgyes szélén kis hajtáscsoportok [8496.3] (2021. 01. 27.).

- Nagycsere településrészen, a Traktoros utca és Cséplő utca sarkán akácosban kisebbnagyobb hajtáscsoportok [8496.4] (2021. 02.17.).

- Bánk, a fehérjefeldolgozó előtti földúton a Diószegi úttól délre, az első tanya melletti akácos foltban szórványos csoportokban [8596.1] (2021. 03.16.).

- Nagy-part, láp mentén, a homokbucka alján vaskos, hosszú hajtások több csoportban [8398.4] (2015. 03.31.). 
- Malomkert (Hanelek), nyírláp szélén szórványos hajtások cserjék alatt [8498.2] (2020. 09.22.).

- Zöld Marci-legelő, füzláp szélén, cserjék alatt kisebb hajtáscsoport [8498.2] (2020. 10.09.).

Hajdúbagos

- Sürü tisztája, egy fiatal tölgyes és nemes nyáras határán levő tuskóprizmán és annak mentén [8696.1] (2020.11. 12.).

Hajdúhadház

- $\quad$ Liget-legelő, buckaközi mélyedésben kevés hajtás [8396.2] (2019. 05. 08.).

- Nagy-erdő, a gázvezeték nyiladéka mentén, erdő szélén ritkás hajtások [8396.1] (2020.07.14.).

Hajdúsámson

- Savós-Kút (vagy Savós-Gút), az erdő keleti szélén húzódó árokban kis csoport [8396.2] (2018. 10.05.).

- Martinkai-legelő, a déli határárokban kisebb-nagyobb foltokban vaskos, hosszú hajtásokkal [8496.2] (2020. 12. 07.). Az állományt Pompola Krisztián (HNPI) találta. A határozás az általa küldött makrofelvételek alapján történt, majd a helyszínen is megvizsgáltuk.

Hosszúpályi

- Hosszú-gaz, tuskóprizmán és környékén 130 méter hosszúságban szórványos [8596.4] (2017. 03. 08.) (mintagyújtés 2020.11. 18.).

- Kossuth-kert keleti szegélyén, erdő szélén szórványos hajtáscsoportok [8596.4] (2018. 12.14.).

Kékcse

- Demeter-szög, rekettyefüzzel becserjésedő magassásos szegélyén, gyomos mezofil gyepben lévő, 80-100 hajtásos állomány [7798.1] (mintagyüjtés: 2020. 08. 13.). Szigetvári Csaba által jelzett lelőhely ismételt felkeresése.

Létavértes

- Mosonta-rét, szőlőskerti homokbucka alján a láp szélénél kevés hajtás, de embermagasságúak is akadnak [8697.1] (2015. 11. 12., mintagyújtés: 2020. 11. 13.). Az állományt Szél László (HNPI) mutatta meg.

Monostorpályi

- Monostorpályi-legelő, a Kis-Pályi-ér mentén. Erdei fenyves szélén és a szomszédos gyep szélén szórványos kisebb hajtáscsoportok [8596.4] (2020. 03. 30.), valamint a Kis-Pályi-ér medrében 40 méter hosszan összefüggő állomány, néhol embermagasságú, vaskos hajtásokkal (2021. 03.18.).

Nyíracsád

- *Csonkás, a Gúti-erdő déli szegélye mentén [8397.4] (2017. 06. 28.).

- Régi-szőlőskert, a nyírlugosi műút árkának oldalában sűrú állomány [8397.4] (2020. 02.11.). Buzita, sürü állomány árokparton [8497.2] (2020.11.11.).

Nyírábrány

- Kis-Mogyorós (Mogyorós-erdő), vizenyős, fehér nyáras erdőrészben és hajdani kubikgödrös terület magyar kőrises erdőállománya alatt [8498.1] (2014. 04. 10. és 2020. 12.18.). 
DEMETER \& LESKU (2021): Az Equisetum × moorei és E. hyemale nyírségi elterjedésének kritikai áttekintése

- Vadon-dúlő, az országhatár mentén, lápos terület melletti bucka alján, fák alatt [8498.1] (2020. 03. 17.).

Nyírbéltek

- Piricse községhatárán futó földút mentén [8298.4] (2018. 10.31.). Barna Péter (HNPI) találta. A határozás az általa küldött habitusképek és makrofelvételek alapján történt.

Nyírcsaholy

- A település északi végén, égerláp szélénél ritkás állomány [8099.4] (2020.12.16.). Megfelel Barczánfalvi Péter (HNPI) 2018-as E. hyemale adatának.

Nyíregyháza

- Sóstói-erdő, vasúti töltésen kisebb-nagyobb hajtáscsoportok hosszabb szakaszon [8096.1] (2020. 12. 16.). Megfelel KoRDA \& SZIGETVÁRI (2013) E. hyemale adatának.

Nyírlugos

- A Gánás-hegytől északkeletre, erdei fenyves szélén kisebb állomány [8398.3] (2020. 02.11.).

Sáránd

- A Hunyadi utca keleti végénél nemes nyárasban szórványos, apró hajtáscsoportok, vékony hajtásokkal [8695.2] (2019.11. 07.). Megfelel Süveges Kristóf 2018-as E. hyemale herbáriumi adatának.

Vámospércs

- Bólya-dűlő, a Monostori-ér forrásági lápjánál homokbucka alján [8597.2] (2001. 03. 09., mintagyüjtés 2019. 05. 16.).

- Kőrises (Jónásrész), az Acsádi-ér hídjánál nagy és sűrű állomány a csatorna partján. [8497.4] (2012.). Pompola Krisztián készített a határozáshoz makrofelvételt 2020. 04. 01-én.

- Kőrises, a zergeboglároknál. Kevés, szórványos hajtás fiatal keményfás ligeterdőben [8497.2] (2019. 02. 25.). Megfelel PAPP (2003) E. hyemale adatának.

- Köteles-dúlő, a debreceni határárokban a Halápi-erdő szélénél egy kis folt [8597.1] (2019. 02.19.).

- Villongó-víztározó, a keleti szivárgó árokban kiterjedt állomány [8497.4] (2019. 11. 07.). Megfelel MATus et al. (2019) E. hyemale adatának.

\section{Herbáriumi vizsgálat}

A Debreceni Egyetem Herbáriumának anyagán is sor került a mikromorfológiai bélyegek vizsgálatára. Ez is megerősíti, hogy Siroki Zoltán 1956-ban gyüjtött három bátorligeti példánya E. hyemale. Siroki E. × moorei-t is gyüjtött a debreceni Nagyerdőben. Az 1947. 06. 21-én szedett három példányból kettőn a következő felirat látható: „Equisetum hiemale L. f. Moorei (Newm.)”. A harmadikon viszont az „Equisetum × moorei (Newm.)” megnevezést használja. Az utóbbi cédulán Soó Rezső neve is szerepel, ezért talán tőle ered az eltérő megnevezés, hiszen ő már a 30-as években is ezt használta. Mivel a Nagyerdőt lefedő KEF kvadrát egyértelműen azonosítható, megadjuk annak kódját is: [8495.2]. Talán érdemes még hozzáfüzni, hogy TAKÁCs et al. (2015) közleményének mellékletében szereplő herbáriumi fajlistában Siroki két első Moore-zsurló példányánál a cédulán olvasható névnek csak az első része szerepel, így félreérthetően téli zsurlóként látható. 
Csak érdekességként jegyezzük meg, hogy Siroki Hortobágyon is gyűjtött Moore-zsurlót (1947, Gyökérkút), viszont pilisszentiváni példányát (Pilisszentiván, Árokparton, 1952. V. 28.) E. ramosissimum-ként azonosítottuk.

A Soó Rezső Herbáriumban a hazai Nyírségre vonatkozóan nem sikerült téli zsurlót kimutatni. Van viszont egy példánya Máthé Imrének a Bátorligettel szomszédos, ma Romániában található Csanálosról (Equisetum hiemale L. cott. Szatmár, in arenosis ad marginem silvae „Csanálosi-erdő” pr. pag. Csanálos. 1942. V. 23.) A címkére tollal valaki helytelenül ráírta, hogy „Moorei Newm”, de ezt már Sramkó Gábor helyreigazította. Egyértelműen Moorezsurlónak bizonyult Matus Gábor vámospércsi Villongóról (2012. 10. 16.) és Süveges Kristóf Sárándról (2018. 09. 16.) származó példánya. Lelőhelyeiket felkeresve a bélyegeket élő növényeken is sikerült ellenőrizni, hála a gyűjtők precíz helymeghatározásának. Itt is van egy olyan adat Felföldy Lajostól, mely TAKÁCS et al. (2014) Soó Rezső Herbáriumról szóló közleményének mellékletében található listán téli zsurlóként értelmezhető, de a teljes felirat valójában a Moore-zsurlóra utal (Equisetum hiemale L. ad var. Moorei /Neum./ verg. Comit. Hajdu, in silva arenosa Apafája erdő pr. opp. Debrecen. 12. III. 1939.), és mi is annak találtuk. Soó Rezsőnek számos E. × moorei példánya van itt, melyek az irodalmi adatait támogatják:

- $\quad$ cott. Szabolcs, in silvis arenosis pr. Bátorliget (occid. Versus) 24. V. 1932.

- cott. Bihar, in silvis arenosis pr. pag. Sáránd 3. IV. 1932.

- cott. Hajdu-Bihar, in silva arenosa Bagaméri erdő pr praed. Szentannapuszta 7. VII. 1933.

- $\quad$ cott. Bihar, in silva arenosa pr. pag. Hosszupályi 10. VII. 1933.

- cott. Bihar, in silva arenosa umbrosa Bagosi erdő pr. pag. Hajdubagos 20. IX. 1933.

- Debrecen, in silva arenosa Pac 3. V. 1934.

- cott. Szatmár, in silva umbrosa Körmei (Fényi) e. inter pag. Mezőfény et Bátorliget 20. V. 1934.

- $\quad$ cott. Hajdu, in silva umbrosa ad stat. Bocskaykert 31. V. 1934.

- cott. Szatmár, in silva umbrosa Bodvai erdő inter pag. Vállaj et praed. Pórháza 4. VIII. 1934.

- cott. Szabolcs, in silva arenosa Külsőguth-erdő pr. Pag. Nyirlugos 29. VI. 1947.

Megemlítjük még, hogy az ELTE Füvészkert herbáriumában (BPU) NóTÁRI et al. (2017) felsorol két E. × moorei példányt Soó Rezsőtől Bátorligetről (1932) és Debrecenből (1938). Ezek felkeresésétől eltekintettünk, mivel várhatóan nem szolgálnak új adalékkal a téma megítéléséhez.

\section{Értékelés}

A Soó Rezső Herbárium anyagában vizsgálatunk szerint tehát vannak hibásan téli zsurlóként azonosított példányok a Nyírségre nézve. Ha ehhez hozzávesszük Polgár Sándor két, Nyírségen kívülről származó, de szintén Moore-zsurlónak bizonyult példányát is (Kunsziget, 1912. VIII. 17.; Győr és Zámoly között, a Kisduna jobb partján, 1915. VI. 21.), akkor 7 lapból csak 3 esetén volt helyes a téli zsurló azonosítása.

A terepi és herbáriumi vizsgálatok segítségével a téli zsurló eddigi hazai nyírségi adatai közül mindössze a bátorligeti lápról származóról tudtuk igazolni, hogy valóban ehhez a taxonhoz tartozik. (Megemlítendő ugyanakkor, hogy a láp területén a Moore-zsurló is előfordul.) Sikertelen volt BoRos (1924) Kispiricsei-erdőből leírt előfordulásának megtalálására tett kísérletünk. Meg kell azonban jegyezni, hogy itt nem található már Boros idejéből származó korú erdő, a jelenlegi faállományok telepítése pedig megítélésünk szerint mindenhol jelentős mértékű talajműveléssel történt. Szintén sikertelen volt Szigetvári Csaba Újfehértóról jelzett állományának felkutatására tett kísérletünk a megadott flóratérképezési kvadrát területén. A 
táj itt részben szikes és egyéb nedves gyepekkel és fasorokkal tagolt mezőgazdasági vidék, ezért elsősorban a vasútvonalat és az árkokat vizsgáltuk. Felkerestük KEVEY et al. (2017) Nyíradonyban jelzett előfordulási helyét is, amit Kevey Balázs rendelkezésünkre bocsátott térképvázlata alapján pontosan azonosítani tudtuk. Sajnos a 2003-ban általa észlelt zsurlókat már nem találtuk. Ennek oka véleményünk szerint a helyszínt azóta ért drasztikus behatásokkal magyarázható. A Gúti-erdő erősen túltartott vadállománya nagyon komoly legelési, taposási és túrási kárt okoz az erdő aljnövényzetében. Ez a vizsgált keményfás ligeterdőfolt esetében is így van. Ráadásul éppen ezt a helyet érte az elmúlt években egy széldöntés, aminek felszámolása szintén jelentős bolygatással járt.

Minden további felkeresett állomány és megvizsgált herbáriumi példány Moore-zsurlónak bizonyult.

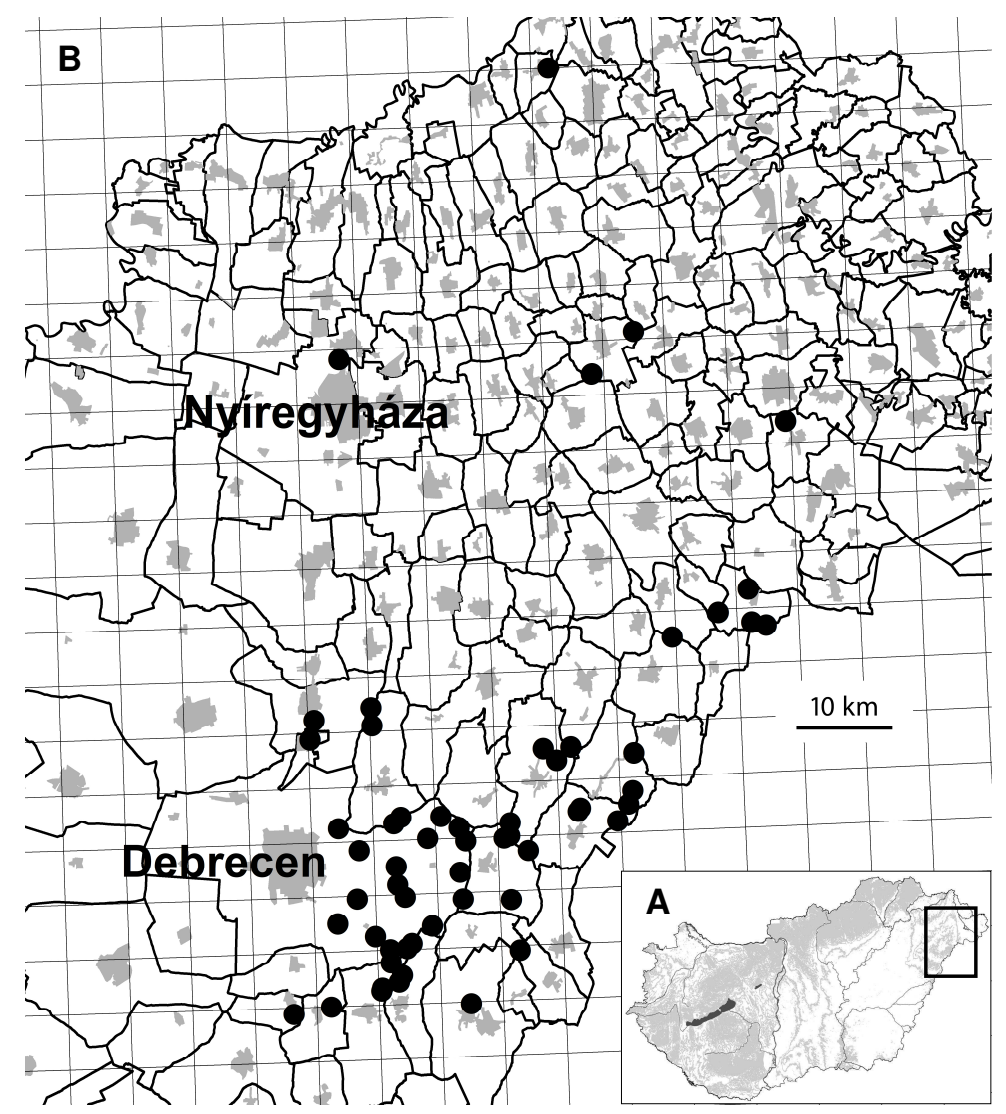

2. ábra (A) A vizsgált terület elhelyezkedése és (B) a Moore-zsurló (Equisetum × moorei) észlelt előfordulási helyei a közép-európai flóratérképezés hálórendszerének (KEF) kvadrátjaival

Fig. 2 (A) Location of the study area and (B) occurrences of Equisetum $\times$ moorei with the quadrats of the Central European flora mapping system (CEU)

A Moore-zsurló a Nyírségben láthatóan széles körben elterjedt (2. ábra). Különösen igaz ez, ha az itt közölt adatainkhoz hozzátesszük a debreceni Nagyerdőt, Apafai-erdőt, a vállaji Bódvaj-erdőt és Bagamért (melyeket csak herbáriumi példányokról, vagy irodalmi adatokból ismerünk), valamint a jelenlegi romániai oldalról származó adatokat. Ez azzal is összefügghet, hogy kedveli a homokos talajú termőhelyeket, ahogy ez a Baltikumban is megfigyelhető (DE WINTER \& LUBIENSKI 2012). Esetleg nem zárható ki a bevezetőben említett „refúgium hatás” sem. 
Gyakran csatornák átereszeinél, hídjainál, árkokban, árokpartokon, illetve lápokat szegélyező homokbuckák alján fordul elő. Kifejezetten száraz termőhelyek kevésbé voltak jellemzőek, bár a vasúti töltések ilyen élőhelynek számítanak, illetve a debreceni Sámsoni úti Bellegelő magas homokbuckája éppen erre kirívó példa. Az előfordulások zöme árnyékos helyen volt, fák, cserjések alatt, vagy legalább időszakosan árnyalt részeken, erdőszéleken. Néhány esetben az állományok térbeli elhelyezkedése arra utal, hogy a vegetatív szétterjedésben szerepe lehetett a talajbolygatásnak. Bocskaikertben például a vasútépítés szórhatott szét a sínek mentén egy hajdani kompaktabb állományt. A sárándi nemes nyárasban és egy bánki fiatalos tölgyesben látható ritkásan szétszórt állományokat az erdőfelújítás során végzett talaj-előkészítés teríthette szét. Szintén az erdei talajművelés eredményei lehetnek a tuskóprizmákon talált állományok. A Nyírségben a tarvágás után kihúzott tuskókat a talaj egy részével együtt tolják össze ilyen prizmákba. A Sámsoni úti Bellegelőn pedig a bucka katonai célú magasításához odaszállított homokkal kerülhetett szokatlanul magas és száraz helyre a növény.

Az általunk vizsgált lelőhelyeken a morfológiai alapon nagyon nehezen elkülöníthető, triploid Equisetum $\times$ ascendens előfordulását nem tapasztaltuk, de a minták citológiai vizsgálata nem történt meg, így elvileg nem is zárható ki teljesen.

Eredményeink alapján úgy gondoljuk, hogy célszerủ lenne felülvizsgálni a téli zsurló régi adatait hazánk más alföldi jellegű élőhelyein is, különösen a folyók mentén és a homokvidékeken. Tapasztalatunk szerint más morfológiai jellegek figyelembevétele mellett a határozáshoz kifejezetten jó támpontot nyújt a levélhüvely magasságának, valamint a hajtások felszínén található kovás kiemelkedések mikromorfológiájának vizsgálata (1. táblázat).

\section{Köszönetnyilvánítás}

Köszönjük Szigetvári Csabának az irodalmak beszerzésében és az általa ismert termőhelyek pontos megadásával nyújtott segítségét, valamint azt, hogy átengedte a Bátorliget-újtanyai adatának közlését. Horváth Ferencnek és Kevey Balázsnak köszönjük az általuk talált növények lelőhelyének pontos megadását. Barna Péternek (HNPI), Szél Lászlónak (HNPI), Patalenszki Norbertnek (HNPI), Pompola Krisztiánnak (HNPI) és Máté Rudolfnak (HNPI) köszönjük, hogy az általuk talált állományok vizsgálatát lehetővé tették, és közlését átengedték. Köszönjük Takács Attilának a herbáriumi anyag áttekintéséhez nyújtott segítségét. Köszönjük Tamás Júlia és Szigetvári Csaba bírálatát és hasznos javaslatait.

\section{Irodalom}

ARdELEAN G. \& KARÁCSONYI K. (2005): Flora, vegetatia, fauna si ecologia nisipurilor din nord-vestul Romaniei. - Daya, Satu Mare, 732 pp.

BARTHA D., BÁN M., SCHMidT D. \& TiBorCz V. (2021): Magyarország edényes növényfajainak online adatbázisa (http://floraatlasz.uni-sopron.hu). - Soproni Egyetem, Erdőmérnöki Kar, Növénytani és Természetvédelmi Intézet.

Boros Á. (1924): Beiträge zur Flora des Nyírség - Adatok a Nyírség Flórájához. - Magyar Botanikai Lapok 23(1-12): 87-90.

BRUNE T., ThIV M. \& HAAS K. (2008): Equisetum (Equisetaceae) species or hybrids? ISSR fingerprinting profiles help improve diagnoses based on morphology and anatomy. - Plant Systematics and Evolution 274: 67-81.

DE WinTER W. \& LUBIEnSKi M. (2012): Equisetum ×ascendens Lubienski \& Bennert: de eerste triploïde paardenstaartbastaard in Nederland. - Gorteria 36: 1-17.

FerRer-Gallego P. P. \& LAguna E. \& Rossello J. A. (2017): Typifications of the Linnaean name Equisetum hyemale and E. × moorei (Equisetaceae). - Phytotaxa 305(2): 104-110. 
FöLDI E. (szerk.) (1981): Magyarország földrajzinév-tára II. - Hajdú-Bihar megye. - Kartográfiai vállalat, Budapest, $40 \mathrm{pp}$.

Horváth F., Csicsek G., Bíró A., Demeter L., Lipka B., Neumann Sz., Papp M., Szegleti Zs., Víg Á. \& Lesku B. (2018): Fényi-erdő - Égett kocka. - ER Füzetek 1, MTA Ökológiai Kutatóközpont, Tihany, 16 pp.

HRoudA L. (1997): Divisio Equisetophyta - rostliny přesličkové. - In: HejNÝ S. \& SLAvíK B. (eds), Květena České republiky 1. Academia, Praha, p. 211.

JávoRKA S. \& Soó R. (1951): A magyar növényvilág kézikönyve I-II. - Akadémiai Kiadó, Budapest, 1120 pp.

JávoRKA S. (1924-1925): Magyar Flóra (Flora Hungarica). Magyarország virágos és edényes virágtalan növényeinek meghatározó kézikönyve. - Studium, Budapest, 1307 pp.

KAlinowsKi P., Sliwinska E. \& Kruk J. (2016): Equisetum $\times$ moorei Newman (Equisetaceae) - a 'new' nothotaxon in the Polish flora. - Biodiversity Research and Conservation 41: 11-18.

Kevey B., PAPP L. \& LENDVAI G. (2017): A Nyírség tölgy-kőris-szil ligetei (Fraxino pannonicae-Ulmetum Soó in Aszód 1935 corr. Soó 1963). - Kitaibelia 22(1): 179-220.

KIRÁLY G. (2009): Sphenopsida - Zsurlók osztálya. - In: KiRÁLY G. (szerk.), Új magyar füvészkönyv. Magyarország hajtásos növényei. Határozókulcsok. Aggteleki Nemzeti Park Igazgatóság, Jósvafő, pp. 72-74.

Korda M. \& Szigetvári Cs. (2013): A Sóstói-erdő védett lágyszárú növényfajai. - In: BARTHA D. (szerk), $A$ Sóstói-erdő. Nyírerdő Nyírségi Erdészeti Zrt., Nyíregyháza, p. 398.

Korda M., Schmidt D., VidéKi R., Haszonits Gy., Tiborcz V., Csiszár Á., Zagyvai G. \& Bartha D. (2017): A Gagea minima (L.) Ker Gawl. és a Dictamnus albus L. újrafelfedezése a Dél-Tiszántúlon, valamint további florisztikai adatok az Alföldről. - Kitaibelia 22(2): 304-316.

KüMmERLE J. B. (1931): Equiseten-Bastarde als verkannte Artformen. - Magyar Botanikai Lapok 30(112): $146-160$.

LUBIENSKI M., JäGER W. \& BENNERT H. W. (2012): Equisetum ×ascendens Lubienski \& Bennert (Subg. Hippochaete, Equisetaceae), eine neue Schachtelhalm-Sippe für die Flora Nordrhein-Westfalens. Jahrbuch des Bochumer Botanischen 3: 7-20.

LUBIENSKI M. (2010): Die Schachtelhalme (Equisetaceae, Pteridophyta) der Flora Deutschlands - ein aktualisierter Bestimmungsschlüssel. - Online-Veröffentlichungen des Bochumer Botanischen Vereins 2(6): 82-100.

Matus G., Aszalós R., Dorotovič Cs., Hanyicska M., HüVös-Récsi A., Musicz L., Miglécz T., PAPP M., Schmotzer A., TöröK P., VAlKó O., VojtKó A., HaRtmann J., TAKÁCs A. \& BAlogh R. (2019): Kiegészítések a magyar flóra ismeretéhez. - Botanikai Közlemények 106(1): 71-112.

NótÁRI K., NAGY T., LÖKI V., LJUBKA T., MolNÁR V. A. \& TAKÁCS A. (2017): Az ELTE Füvészkert herbáriuma (BPU). - Kitaibelia 22(1): 55-59.

ÖTvös J. (1965): A Fényi erdő. - A Debreceni Déri Múzeum 1964. évi Évkönyve 47: 303-313.

PAPP L. (2003): Vámospércs-Nyíracsád Jónás rész tanösvény. - Dél-Nyírség-Bihari Tájvédelmi Egyesület, Debrecen, p. 10.

PAPP M. \& LESKU B. (2002): Bátorligeti láp természetvédelmi terület. - In: LENTI I. \& ARADI Cs. (szerk.), Bátorliget élóvilága - ma. Bátorliget, pp. 9-24.

Pétrement B., Bizot A. \& Krippel Y. (2012): Equisetum × moorei Newman (Equisetaceae, Pteridophyta), taxon nouveau pour le Luxembourg. - Bulletin de la Société des naturalistes luxembourgeois 113: 8390.

RAPAICS R. (1922): Újabb adatok Debreczen növényzetének ismeretéhez. - Magyar Botanikai Lapok 21(1-12): 16-17.

RÉv Sz., PAPP M., LESKU B. \& BudAY A. (2005): A bátorligeti Fényi-erdő flórája. - Kitaibelia 10(1): 48-64.

SEREGÉLYES T. (1999): Equisetum hyemale L. - Téli zsurló. - In: FARKAS S. (szerk.), Magyarország védett növényei. Mezőgazda Kiadó, Budapest, p. 81.

Simon T. (2000): A magyarországi edényes flóra határozója. Harasztok - Virágos növények. - Nemzeti Tankönyvkiadó, Budapest, p. 63.

Soó R. \& KÁRPÁTI Z. (1968): Növényhatározó II. Harasztok - virágos növények. - Tankönyvkiadó, Budapest, $846 \mathrm{pp}$.

Soó R. (1932): Debrecen növényvilágának kutatása. Újabb adatok Hajdúmegye flórájának ismeretéhez. Debreceni Szemle 6(6): 216-225.

Soó R. (1934): Nyírség-kutatásunk florisztikai eredményei. - Botanikai Közlemények 31(5-6): 218-252.

Soó R. (1937): Pótlékok Nyírségi flórakutatásunk eredményeihez. - Botanikai Közlemények 34(1-2): 3344. 
Soó R. (1964): A magyar flóra és vegetáció rendszertani és növényföldrajzi kézikönyve I. - Akadémiai Kiadó, Budapest, pp. 519-520.

STACE C. (2010): New flora of the British Isles. Third edition. - Cambridge University Press, Cambridge, pp. 11-14.

StANDOváR T., Tóth Z. \& Simon T. (1991): Vegetetion of the Bátorliget Mire Reserve. - In: MAhunKa S. (ed.), The Bátorliget Nature Reserves - after forty years. Hungarian Natural History Museum, Budapest. 1: 57-118.

TAKÁcs A., SÜveges K., LjubKa T., LÖKI V., LisZTes-Szabó Zs. \& Molnár V. A. (2015): A Debreceni Egyetem Herbáriuma (DE) II.: A „Siroki Zoltán Herbárium”. - Kitaibelia 20(1): 15-22.

TiNYA F. (2005): A Bátorligeti Ốsláp Természetvédelmi Terület növényvilága. - Szakdolgozat, ELTE Növényrendszertani és Ökológiai Tanszék, Budapest, 86 pp.

UBRIZSY G. (1936): A nyíregyházi erdő növényformációi. - Szabolcsi Szemle 3(7-10): 244-254.

WATSON L. \& DALLWiTz M. J. (2004) The Equisetum species (horsetails) of Britain and Ireland. - Version: 5th August 2019. https://www.delta-intkey.com/britht/www/moorei.htm

Webb D. A., PARnell J. \& Doogue D. (1996): An Irish Flora. - Dundalgan Press (W. Tempest) LTD., Dundalk, p. 4.

\section{Világháló-oldalak}

[1] MBFSZ térképszerver https://map.mbfsz.gov.hu/fdt100/ (Hozzáférés: 2020. 12. 19.)

[2] Plant Crib https://www.ebps.org.uk/wp-content/uploads/2014/04/Equisetum.pdf (Hozzáférés: 2019. 01.26.)

Beérkezett / received: 2021. 02. 21. • Elfogadva / accepted: 2021. 04. 18.

\section{Elektronikus melléklet}

e1. ábra Három zsurlófaj levélhüvelye. A: Equisetum hyemale; B: E. × moorei; C: E. ramosissimum két fekete gyürűvel és maradó fogakkal

Fig. e1 Leaf-sheaths of three horsetails. A: Equisetum hyemale; B: E. × moorei; C: E. ramosissimum with two black bands and permanent teeth

e2. ábra Equisetum hyemale hajtásának felszíne (makrofotó)

Fig. e2 The surface of Equisetum hyemale shoots (macrophoto)

e3. ábra Equisetum $\times$ moorei hajtásának felszíne (makrofotó)

Fig. e3 The surface of Equisetum $\times$ moorei shoots (macrophoto)

e4. ábra Equisetum $\times$ moorei hajtásának felszíne (borult időben készült makrofotó)

Fig. e4 The surface of Equisetum × moorei shoots (macrophoto taken in overcast weather)

e5. ábra Equisetum × moorei hajtásának felszíne (USB mikroszkóp)

Fig. e5 The surface of Equisetum $\times$ moorei shoots (USB microscope)

e6. ábra Equisetum $\times$ moorei ritkás állománya

Fig. e6 Sparse stand of Equisetum $\times$ moorei

e7. ábra Equisetum hyemale sűrű állománya leszáradó hajtásvégekkel márciusban

Fig. e7 Dense stand of Equisetum hyemale with drying shoot ends in March

e8. ábra Equisetum $\times$ moorei sűrű állománya

Fig. e8 Dense stand of Equisetum $\times$ moorei

e9. ábra Equisetum hyemale Bátorligeten

Fig. e9 Equisetum hyemale in Bátorliget 
DEMETER L. \& LESKU B. (2021):

Az Equisetum × moorei és E. hyemale nyírségi elterjedésének kritikai áttekintése / Critical review of the distribution of Equisetum × moorei and E. hyemale in the Nyírség (East Hungary)

Kitaibelia 26(2): 131-144.

DOI: $10.17542 /$ kit.26.131

Elektronikus melléklet / Electronic appendix
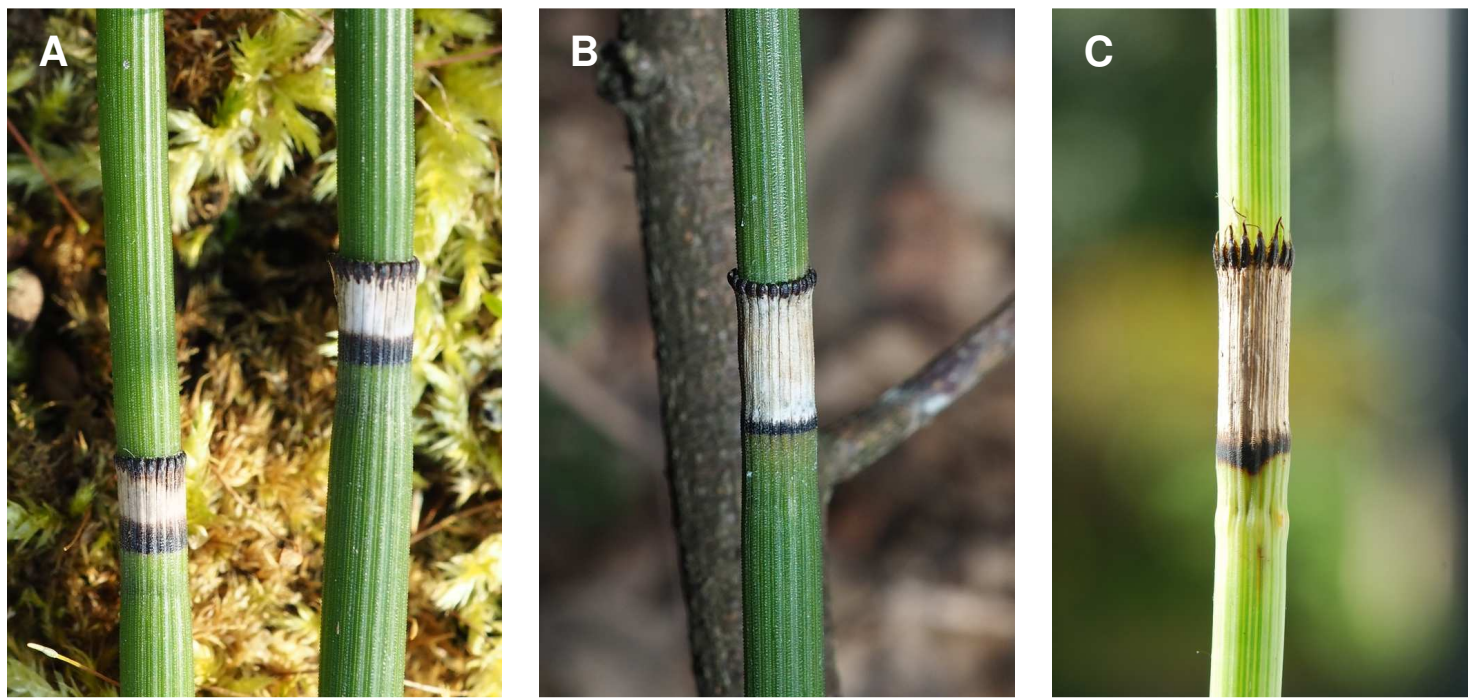

e1. ábra Három zsurlófaj levélhüvelye. A: Equisetum hyemale; B: E. × moorei; C: E. ramosissimum két fekete gyűrűvel és maradó fogakkal

Fig. e1 Leaf-sheaths of three horsetails. A: Equisetum hyemale; B: E. × moorei; C: E. ramosissimum with two black bands and permanent teeth

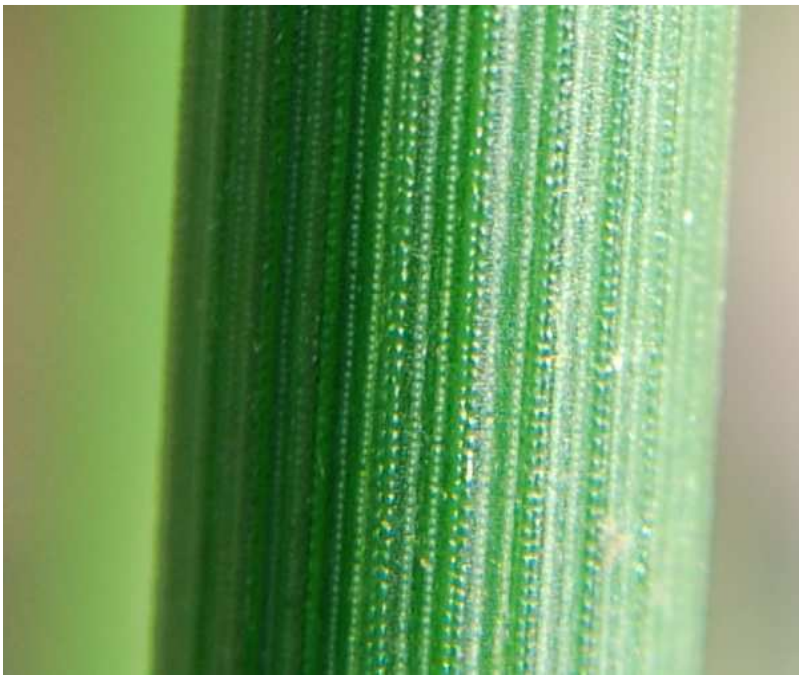

e2. ábra Equisetum hyemale hajtásának felszíne (makrofotó)

Fig. e2 The surface of Equisetum hyemale shoots (macrophoto)

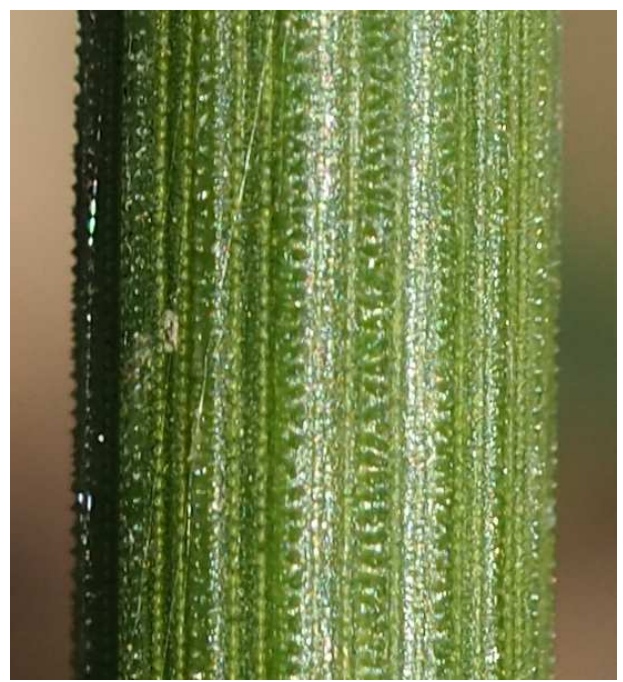

e3. ábra Equisetum × moorei hajtásának felszíne (makrofotó)

Fig. e3 The surface of Equisetum $\times$ moorei shoots (macrophoto) 


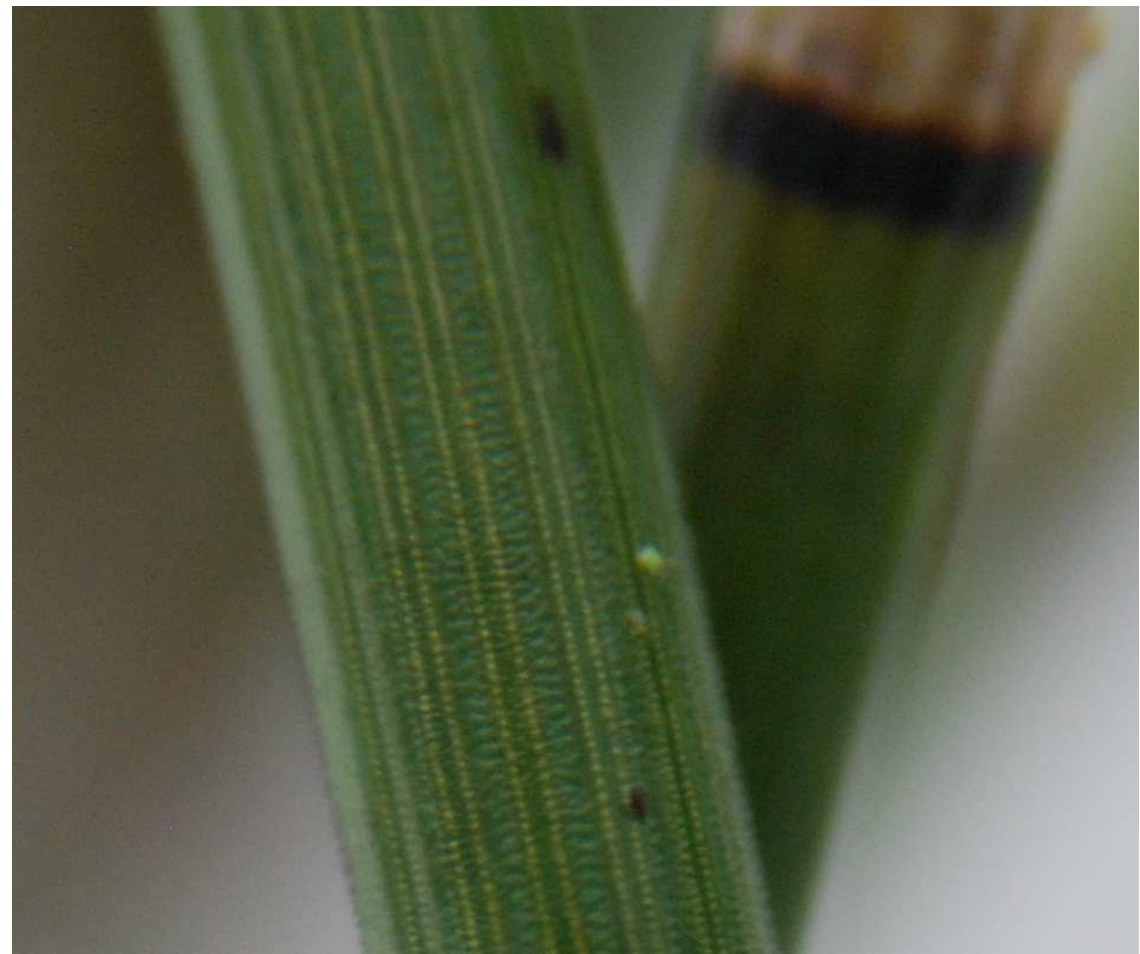

e4. ábra Equisetum × moorei hajtásának felszíne (borult időben készült makrofotó) Fig. e4 The surface of Equisetum $\times$ moorei shoots (macrophoto taken in overcast weather)

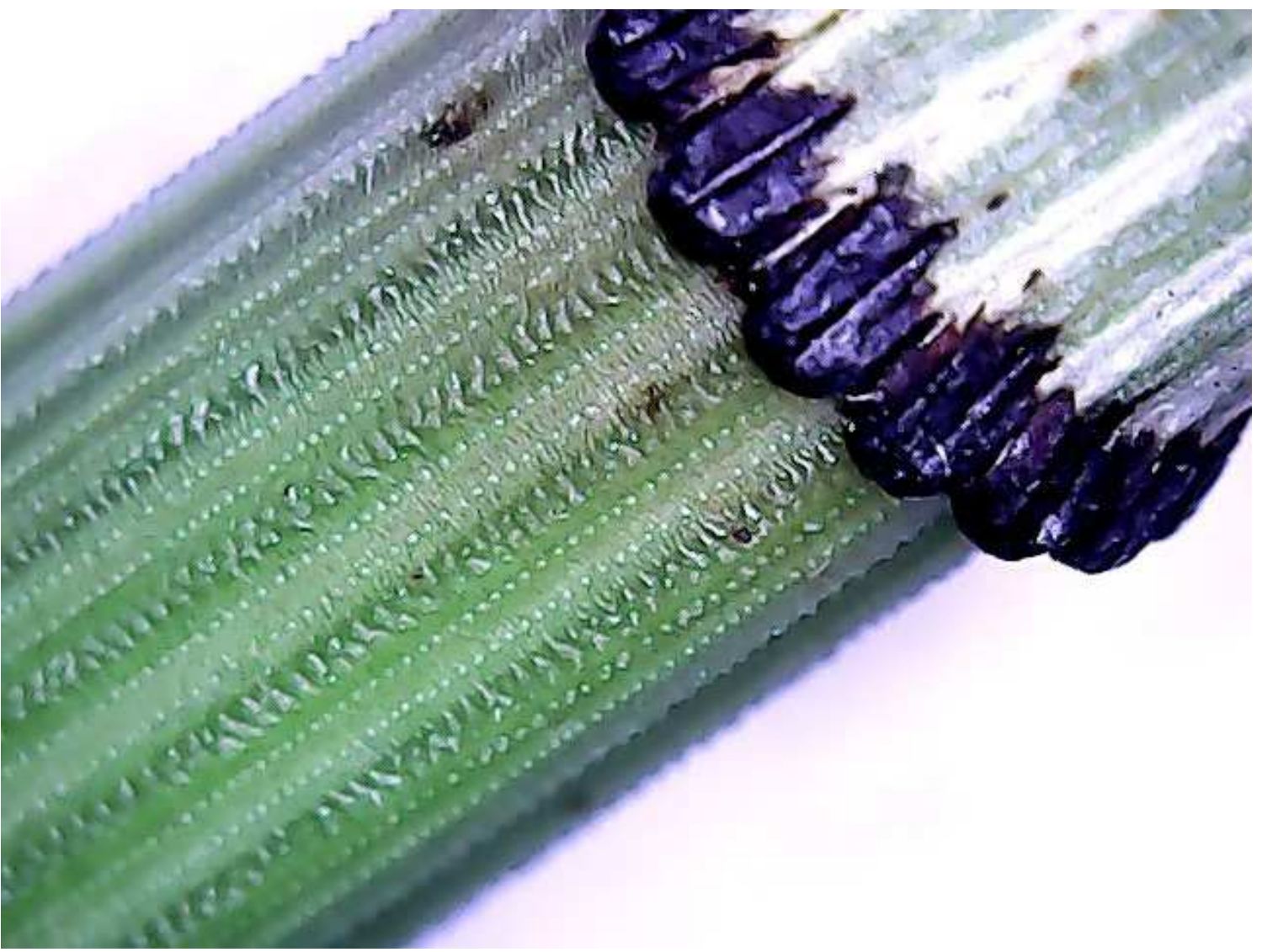

e5. ábra Equisetum × moorei hajtásának felszíne (USB mikroszkóp) Fig. e5 The surface of Equisetum $\times$ moorei shoots (USB microscope) 


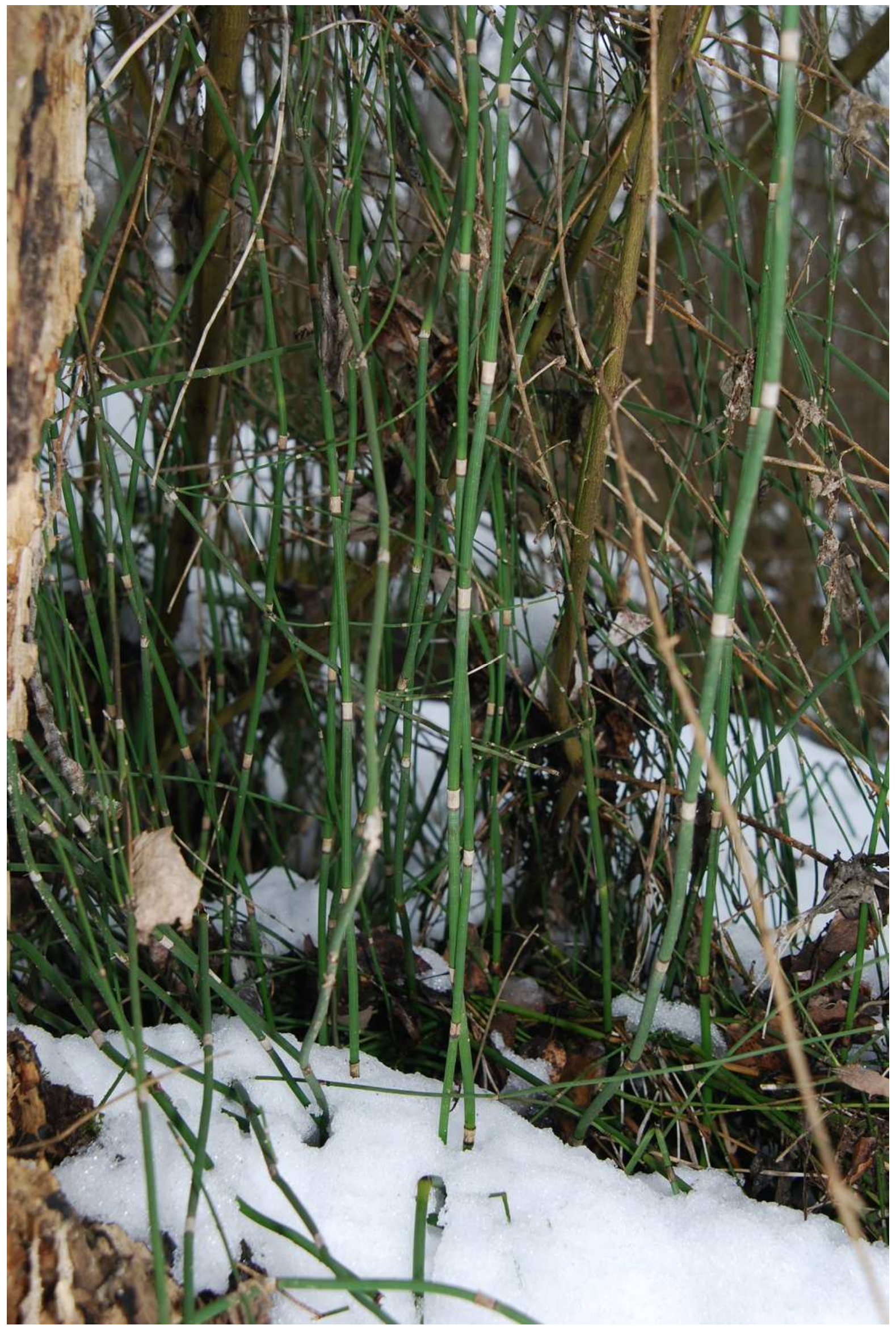

e6. ábra Equisetum $\times$ moorei ritkás állománya

Fig. e6 Sparse stand of Equisetum $\times$ moorei 


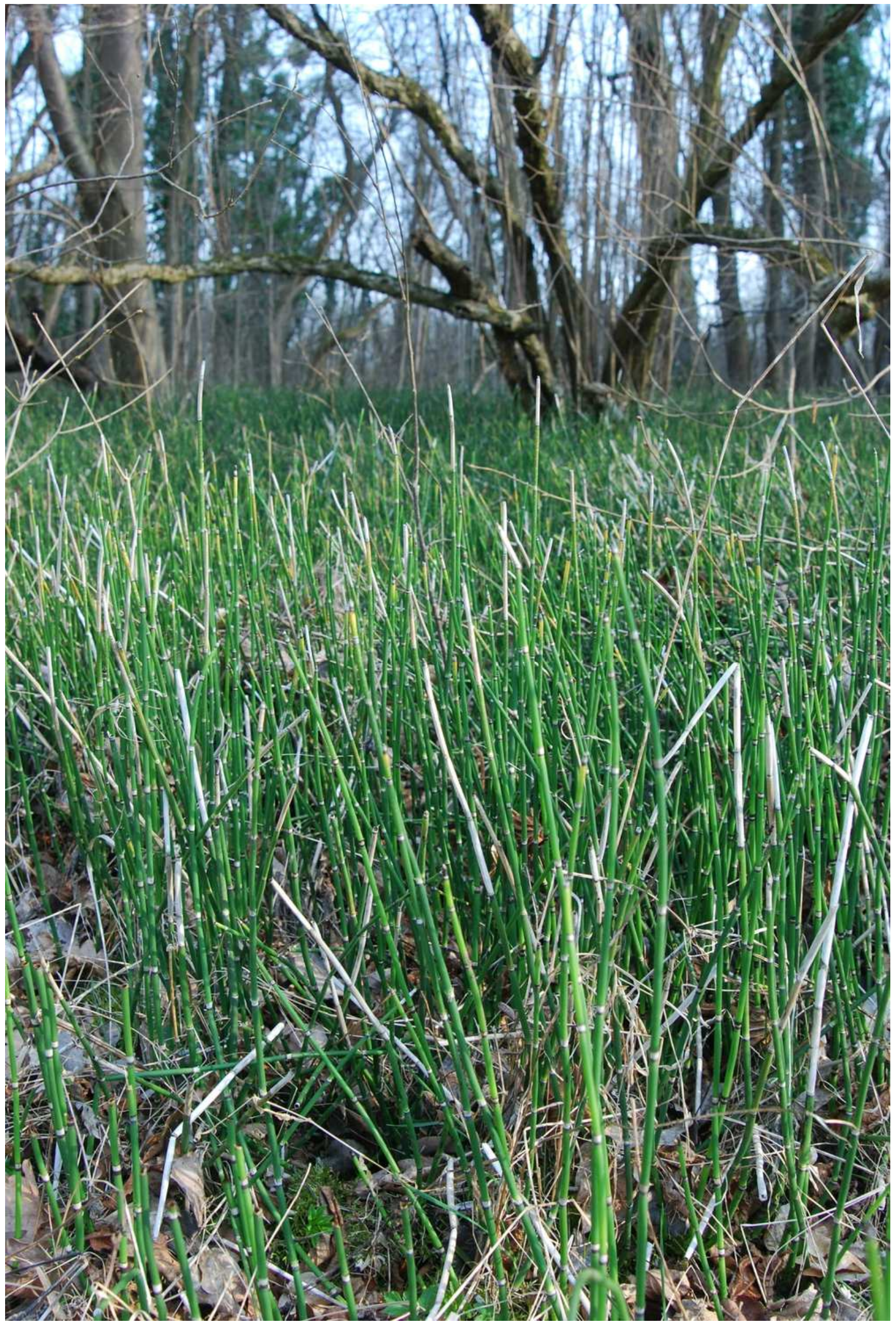

e7. ábra Equisetum hyemale sűrű állománya leszáradó hajtásvégekkel márciusban

Fig. e7 Dense stand of Equisetum hyemale with drying shoot ends in March 


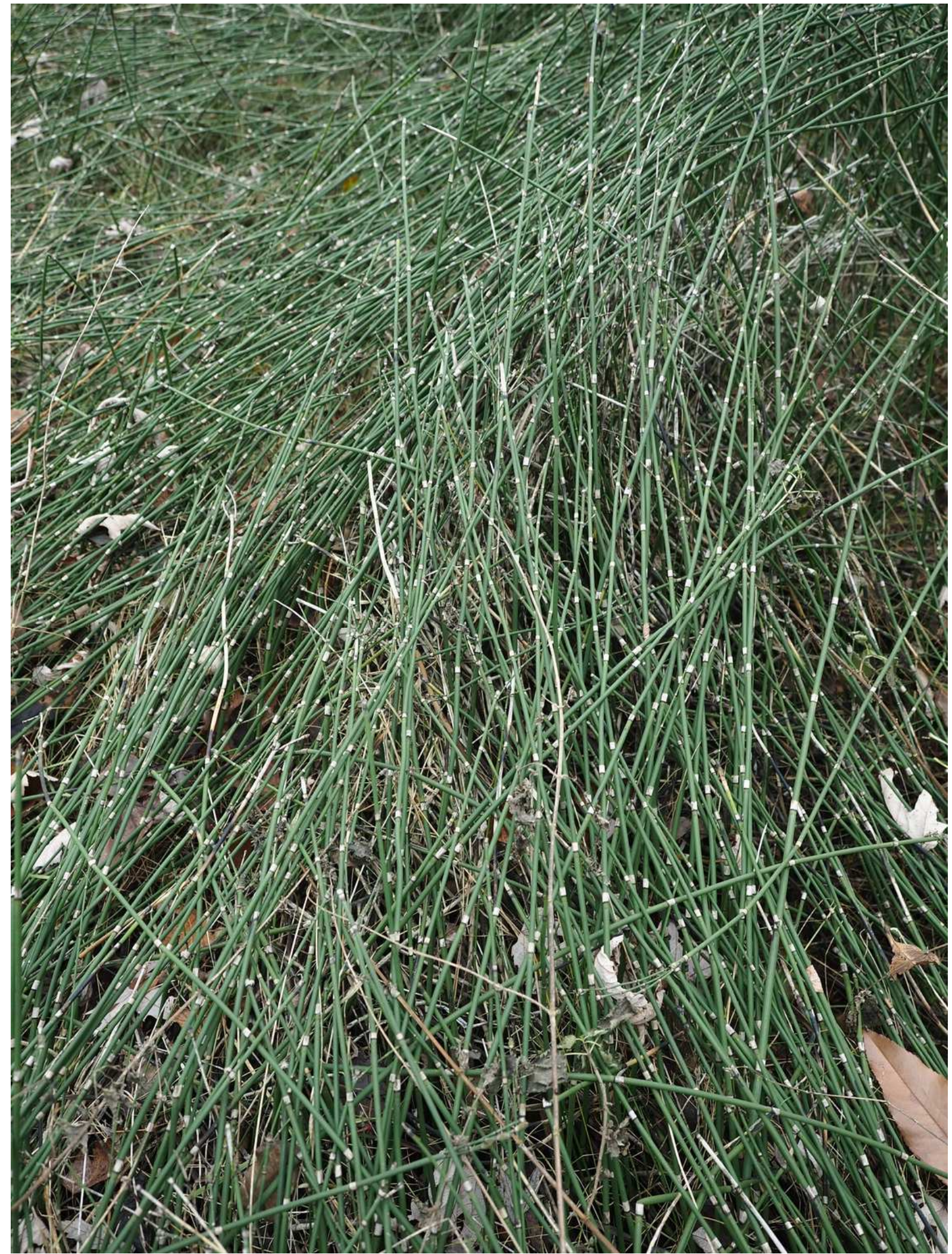

e8. ábra Equisetum $\times$ moorei sűrű állománya

Fig. e8 Dense stand of Equisetum $\times$ moorei 


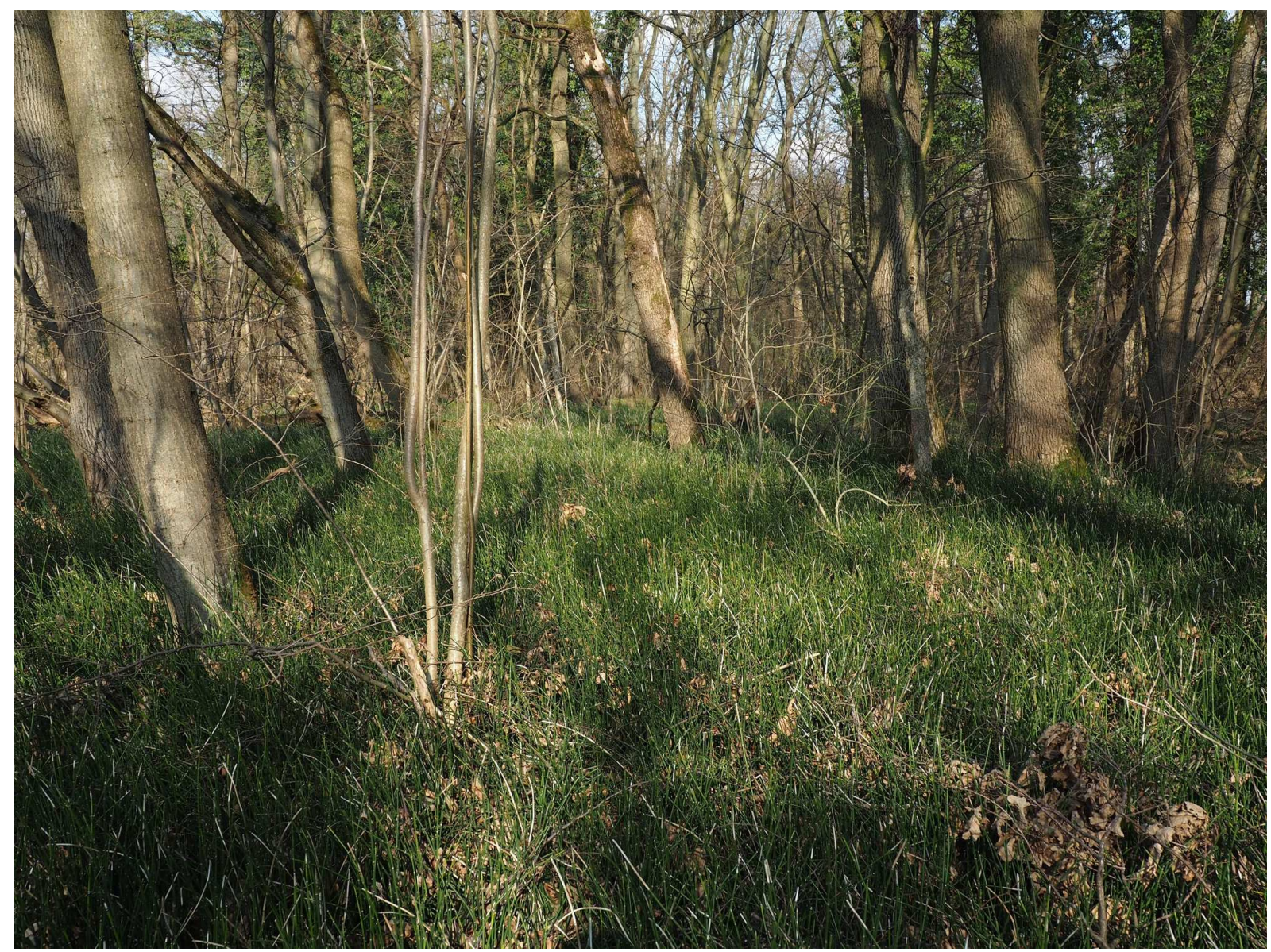

e9. ábra Equisetum hyemale Bátorligeten

Fig. e9 Equisetum hyemale in Bátorliget 